\title{
RISK ANALYSIS AND MANAGEMENT OF PROCUREMENT ACTIVITIES INELEMENTARY SCHOOL BOOK PRINTING PROJECT USING HOUSE OF RISK METHOD
}

\author{
Ananda Vania Arisa Putri*, Rheza Aulia Ramadhan*, Bambang Purwanggono \\ Sukarsono*
}

\author{
Industrial Engineering Department Faculty of Engineering Diponegoro University
}

Semarang, Indonesia

\begin{abstract}
Risk management is a management effort to control the company's risk operations by conducting risk analysis, risk evaluation and mitigation plan. Risk management efforts are feasible to be applied to the company's business activities including procurement activities. PT XYZ is one of the printing companies whose main demand is the printing of Elementary School Books. There is a decrease in demand that results in disruption to the company's cash flow so that a tight money policy is applied to every company's activity including procurement activities. This policy increases the risk that may occur, so risk management efforts are needed to minimize the impact that can occur. The House of Risk method is used to identify risk events and risk agents that cause them, and design mitigation measures to address those risk agents. The results showed that there were 10 risk events and 10 identified risk agents, with priority risk agents to be handled are A1 (volume and type of raw materials are incorrect) and A3 (communication interruption). There are 5 recommended mitigation measures.
\end{abstract}

Keywords: House of Risk; risk management; supply chain management

\section{Introduction}

Procurement is the acquisition of goods or services. It is advantageous that the goods or services are appropriate and that they are purchased at the best cost to meet the needs of the buyer in terms of quality and quantity,time, and location (Weele, 2010). The large influence of procurement on the sustainability of the company's businessalso makes the procurement process requires good risk control. Without structured risk management, the impact on the company's performance will be great.

From previous research mentioned that the company can experience a shortage of raw material supplies in warehouses (Yuliawati, 2015). Suppliers are unable to meet demand, resulting in the company not being able to get the raw materials needed and hampering the production schedule. Contracts that are not adhered to by suppliers occur due to improper relationships.

The dynamics that occur in this procurement raises a variety of risks that can have a big impact on the sustainability of the company's business. A risk assessment is needed to design countermeasures against possible risks and impacts. The House of Risk (HOR) model offers a framework for proactive risk control,

*Penulis Korespondensi.

E-Mail: anandavaniaap@students.undip.ac.id, rhezaauliaramadhan@students.undip.ac.id, bambangpurwanggono@lecturer.undip.ac.id enabling companies to develop proactive activities in tackling risks arising from risk agents (Geraldine, 2009).

The purpose of this research is to identify and measure the impact of risks in procurement activities, find riskagents, or cause risks from emerging risks, and provide risk mitigation recommendations to $\mathrm{PT} X Y Z$, so that companies can conduct proactive evaluations of raw material procurement to avoid risks that can hinder the company's logistics activities and elementary school book printing activities. PT XYZ is a company engaged in printing, especially in printing elementary school books. PT XYZ is one of the largest publishers of Grasindo books and a printing provider in East Kalimantan. PT XYZ prints 10,000 copies of the book every day. Since March 2021, Grasindo decided to move some of its book production to another company. This was responded by PT XYZ by issuing a policy of tight money in all funding procurement activities. Financial policy that previously could meet production needs in three months was hampered and made the financial dynamics change.

\section{Literature Review}

Risk is defined as the probability of an event causing a loss and the potential magnitude of the event. Risk management is the art of decision-making in a world full of uncertainty. House of Risk is the development of QFD (Quality Function Deployment) and FMEA (Failure Modes and Effect Analysis) methods used to develop a framework for managing risk. This method aims not only to counter the risk but 
Table 1. Identify Risk Events

\begin{tabular}{|c|c|c|}
\hline No. & Risk Event (Ei) & Severity of Risk (Si) \\
\hline E1 & Production failure. & 3 \\
\hline E2 & There are obstacles in the production process. & 4 \\
\hline E3 & Overbooked raw materials. & 2 \\
\hline E4 & Poor quality of raw materials. & 5 \\
\hline E5 & There's no stock in the warehouse. & 3 \\
\hline E6 & Lack of raw materials. & 3 \\
\hline E7 & Rising prices of raw materials. & 1 \\
\hline E8 & Production equipment is no longer viable. & 3 \\
\hline E9 & Delay in supply of raw materials into the hands of manufacturers. & 3 \\
\hline E10 & Changes in production schedule & 1 \\
\hline
\end{tabular}

also to counter the causes of risk orrisk agent. HOR has two phases, the first is risk identification, the output is a priority rating risk agent. The second phase is risk management, the output is in the form of a plan of preventive measures for the occurrence of risk agents.

Failure Mode and Effect Analysis (FMEA) is considered quite representative in assessing risks in the supply chain. In addition, this method is also considered by practitioners and academics as the most suitable method to assess the risks arising in a supply chain process (Tang, 2006). Understanding Quality Function Deployment (QFD) is a structured methodology used in the process of designing and developing products to establish the specifications of consumer needs and wants, as well as systematically evaluate the capabilities of products or services in meeting needs and wants (Sinha, 2004). follows:

The steps of applying the HOR model are as

1. HOR Phase 1

a. Identification of risk event (Ei) and risk agent (Aj) and calculation of occurrence and severity of $\mathrm{Ei}$ and $\mathrm{Aj}$ variables

b. Build a matrix of correlation relationships Ei and $\mathrm{Aj}$ with provisions, 0 : no correlation, 1 : weakcorrelation, 3: moderate correlation and 9: strong correlation.

c. Calculation of ARP value from Aj using formula:

d. ARP rating of each $\mathrm{Aj}$

$$
A R P_{j}=0_{j} . \Sigma S_{i} \cdot R_{i j}
$$

e. Aj pareto diagramming (Aj priority selection)

2. HOR Phase 2

a. Preparation of mitigation or preventive action based on Aj's priorities

b. Aj correlation relationship and mitigation with provisions $0,1,3$ and 9 .

c. Calculation of the total effectiveness of each mitigation with the formula:

$$
T E_{k}=\Sigma\left(A R P_{j} . E_{j k}\right)
$$

d. Measurement of the degree of difficulty of application of mitigation with a scale of applicationdifficulty of 3: low, 4: medium and 5: high.

e. Calculation of Effectiveness to difficulty ratio with formula:

$$
E T D_{k}=T E_{k} / D_{k}
$$

f. Rating of mitigation priorities based on value $E T D_{k}$

\section{Methods}

The research method was conducted starting with preliminary research conducted at PT XYZ, especially in the logistics division of elementary school books. Preliminary research is also conducted to determine the current situation regarding ongoing procurement activities. In this study, the first House of Risk (HOR) was conducted on the general business process of procurement and the second was conducted on the business process of each material and components of high-risk category. In this study consists of 3 stages, namely:

a. Data Collection and Processing Stage

At this stage is carried out on the general business process of procurement and on the business process of procurement of each material category high risk. This stage is carried out identification of risk event and risk agent. Then the measurement of occurrence and severity is done using questionnaires. Then done HOR phase 1 is a link between risk event and risk agent to get a risk agent that becomes a priority. Furthermore, HOR phase 2 is related to risk agent and preventive action to produce effective preventive action.

b. Analysis and Discussion Stage

At this stage, analysis is carried out on the results of HOR phase 1 and HOR phase 2 to see the internal or external factors that have an effect. And analysis of preventive action.

c. Conclusion Stage

The withdrawal of conclusions is based on the formulation of the problem and the objectives set out in the investigation.

\section{Result and Discussion}

In the preliminary research conducted brainstorming activities with PT XYZ. Interviews are conducted to identify what risk events and risk agents may occur in the company's procurement activities. The incidence of risk that was successfully identified and assessed severity of risk ( $\mathrm{Si}$ ) can be seen in Table 1.

The risk agent $(\mathrm{Aj})$ that was successfully identified and assessed its occurrence level $(\mathrm{Oj})$ and 
Table 2. Identification of Risk Agents

\begin{tabular}{clc}
\hline No. & \multicolumn{1}{c}{ Risk Agent $(\mathbf{A j})$} & $\boldsymbol{O} \mathbf{j}$ \\
\hline A1 & The volume and type of raw materials are incorrect. & 1 \\
A2 & Lack of resource competence. & 2 \\
A3 & Communication breakdown. & 2 \\
A4 & There are no quality inspection standards. & 3 \\
A5 & No procurement SOP is applied. & 2 \\
A6 & Does not open the possibility for other suppliers. & 2 \\
A7 & Erratic weather conditions & 4 \\
A8 & There is no exact timetable for when maintenance on the & 3 \\
& production machine will be carried out. & 5 \\
A9 & Lack of oversight from superiors. & 2 \\
A10 & Sudden demand from consumers. & \\
\hline
\end{tabular}

Table 3. HOR Phase 1 Calculation

\begin{tabular}{|c|c|c|c|c|c|c|c|c|c|c|c|}
\hline \multirow{2}{*}{$\begin{array}{l}\text { Risk Event } \\
\text { (Ei) }\end{array}$} & \multicolumn{10}{|c|}{ Risk Agent (Aj) } & \multirow{2}{*}{$\begin{array}{c}\text { Severity of } \\
\text { Risk (Si) }\end{array}$} \\
\hline & A1 & $\mathbf{A 2}$ & A3 & A4 & A5 & A6 & A7 & A8 & A9 & A10 & \\
\hline E1 & 9 & 3 & 3 & 3 & 1 & & 1 & 1 & 1 & & 5 \\
\hline E2 & & 9 & 3 & & 3 & & 3 & 1 & & & 4 \\
\hline E3 & 3 & 1 & 3 & & 1 & & & & 1 & & 2 \\
\hline E4 & & 3 & 3 & 9 & & & & & & & 5 \\
\hline E5 & 1 & 1 & 9 & & 9 & 1 & 1 & & 1 & 1 & 3 \\
\hline E6 & 1 & 1 & 3 & & 1 & 3 & 1 & & & & 3 \\
\hline E7 & & & 3 & & & 1 & 1 & & & 3 & 1 \\
\hline E8 & & 1 & 1 & 3 & & & & 9 & 1 & & 3 \\
\hline E9 & 3 & 1 & 9 & & 1 & 1 & 1 & & 1 & & 3 \\
\hline E10 & & 3 & 9 & & 1 & 1 & & 3 & & 3 & 1 \\
\hline Occ $(\mathrm{Oj})$ & 5 & 2 & 2 & 3 & 2 & 2 & 4 & 3 & 1 & 2 & \\
\hline ARP & 330 & 166 & 252 & 207 & 106 & 34 & 108 & 117 & 16 & 18 & \\
\hline Priority & 3 & 2 & 1 & 7 & 4 & 6 & 5 & 9 & 8 & 10 & \\
\hline & & & & \multicolumn{8}{|c|}{ Table 4. Pareto Calculation } \\
\hline Risk Agent & Rank & ARP & & RP Cum. & & $\mathbf{R P}(\%)$ & & Percent & Cum. & & Category \\
\hline $\bar{A} 1$ & 1 & 303 & & 303 & & 22.83 & & & 83 & & Priority \\
\hline A3 & 2 & 252 & & 555 & & 18.99 & & & 82 & & \\
\hline A4 & 3 & 207 & & 762 & & 15.60 & & & 42 & & \\
\hline $\mathrm{A} 2$ & 4 & 166 & & 928 & & 12.51 & & & 93 & & \\
\hline A8 & 5 & 117 & & 1045 & & 8.82 & & & 75 & & Non-Priority \\
\hline A7 & 6 & 108 & & 1153 & & 8.14 & & & 89 & & \\
\hline A5 & 7 & 106 & & 1259 & & 7.99 & & & 88 & & \\
\hline A6 & 8 & 34 & & 1293 & & 2.56 & & & 44 & & \\
\hline A10 & 9 & 18 & & 1311 & & 1.36 & & & 79 & & \\
\hline A9 & 10 & 16 & & 1327 & & 1.21 & & & .00 & & \\
\hline
\end{tabular}

listed there is Table 2. Aj and Oj's value is based on interviews with procurement managers.

\subsection{Numerical Result}

Next will be discussed about the measurement of correlation values (Rij) and the calculation of risk priorityindex (ARP) values. This value will be used as a consideration to determine the priority of risk management that willbe the input for HOR Phase 2. The measurement of correlation values and ARP calculations can be seen in Table 3 .

After all risk agents are calculated ARP value, then the next step is to group the risk agents if it will be a mitigation action. Determination of such risk agents using Pareto law. Pareto's law states that $80 \%$ of problems are caused by $20 \%$ critical risk. By focusing countermeasures on $20 \%$ risk, it is expected that $80 \%$ of the company's risk impact can be minimized or even resolved Table 4 is a pareto calculation of risk agents. From Table 4 it is obtained that $20 \%$ of the risk causes come from two risk agents namely volume and type of improper raw materials (A1) and communication interruption (A3).

After processing in HOR phase 1 and obtaining ARP value, then the next stage of risk mitigation by using HOR phase 2 is to handle (risk treatment). The identified risk agent has the largest ARP value determined by pareto diagram will be the input in HOR 


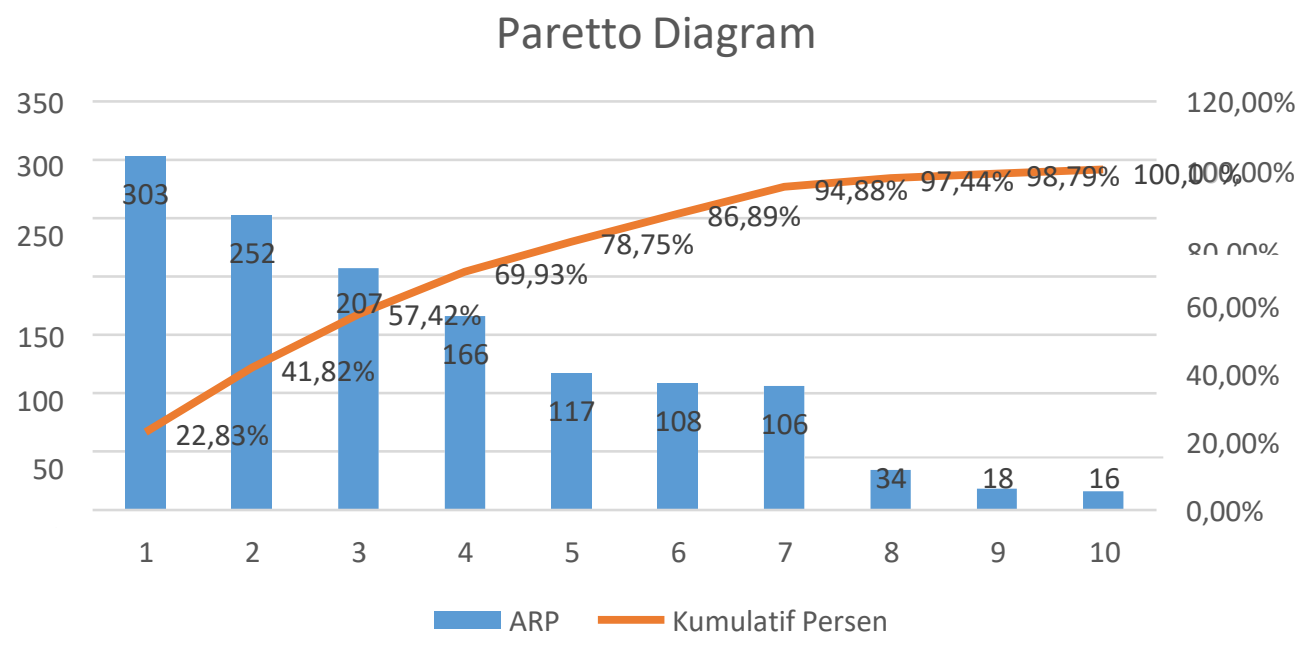

Figure 1. Pareto Diagram

Table 5. Identification of Mitigation Actions

\begin{tabular}{lll}
\hline \multicolumn{1}{c}{ Risk Agent } & \multicolumn{1}{c}{ Mitigation Actions } & Mitigation Code (PA) \\
\hline \multirow{3}{*}{ Volume dan tipe bahanbaku tidak tepat. (A1) } & Melakukan evaluasi kinerja supplier & PA1 \\
& Peninjauan sistem efektivitas untuk aktivitas & PA2 \\
& pengadaan & PA3 \\
Gangguan komunikasi. (A3) & Melakukan pelatihan secara berkala & PA4 \\
& Melakukan pengukuran kinerja & PA5 \\
& Melakukan evaluasi efektifitas komunikasi & \\
\hline
\end{tabular}

Table 6. HOR Phase 2 Calculation

\begin{tabular}{lcccccc}
\hline \multirow{2}{*}{ Risk Agent } & \multicolumn{5}{c}{ Mitigation Action (PAk) } \\
\cline { 2 - 6 } & PA1 & PA2 & PA3 & PA4 & PA5 & ARP \\
\hline A1 & 9 & 9 & 1 & & 1 & 303 \\
A3 & 1 & 1 & & 3 & 3 & 252 \\
\hline Total effectiveness of action (Tk) & 2979 & 2979 & 303 & 756 & 1059 \\
\hline Degree of difficulty performing action (Dk) & 4 & 3 & 3 & 3 & 4 \\
\hline Effectiveness to difficulty ratio (ETD) & 744.75 & 993 & 101 & 252 & 264.75 \\
\hline Rank & 2 & 1 & 5 & 4 & 3 \\
\hline
\end{tabular}

phase 2 which is the priority risk that will be mitigated.

Based on the calculation of ARP in HOR phase 1,

a pareto diagram is created to determine the risk agent that causes risk to the system. The percentage of $20 \%$ entry in A3 with cumulative up to $41.82 \%$ so that A3 is included inthe risk agent that must be addressed. Here is a list of risk agents that will be mitigated based on ARP values by using pareto diagram on Figure 1.

\section{House of Risk Phase 2}

At this stage, follow-up on priority risk agents will be given mitigation action to minimize the impact of the risk agent. The first step is to identify the ideal mitigation action to address priority risk agents. This identification is obtained through brainstorming activities. Here Table $\mathbf{5}$ is a mitigation action to address each risk agent.

After the identification of mitigation actions, the measurement of correlation value between mitigation action and priority risk agent is carried out. The correlation value is still the same as the correlation value between the risk agent and the risk event. Furthermore, the calculation of the degree of difficulty (Dk). This degree of difficulty is as an overview of the difficulty level of the implementation of mitigation actions. The value scale used is based on a value scale of 3 weights for easy-to-implement mitigation actions, 4 for mitigation actions that are somewhat difficult to implement, and weight 5 for mitigation actions that are difficult to implement.

The next step is to calculate the total effectiveness (TEk) by summing the results of the correlation value matching the ARP of each priority risk agent. After that calculate the value of effectiveness to difficulty ratio (ETD) by dividing the value of TEk with Dk. Etd value is the benchmark or parameter of mitigation action based on the order of ease of implementation, so that as high as the value of ETD then mitigation action is increasingly considered ideal to be implemented. Calculations can be seen on Table 6.

Based on the table, it is concluded that the most ideal mitigation for the company to implement today is a review of the effectiveness system for procurement activities (PA2). Mitigation actions are sorted from those 
with the largest tosmallest ETD values.

Recommendations for mitigation actions that can be given assembled research results are:

1. Review of the effectiveness system for procurement activities (PA2).

Risk mitigation action with the highest rank with a tk value of 5035, a difficulty degree value (Dk) of 3 , andfor an ETD value of 1678.3. In reviewing the effectiveness system for procurement activities need to look at related factors to maximize in making improvements.

2. Evaluate supplier performance (PA1).

Risk mitigation action with the second rank that has Tk of 4725, Dk value of 4, and ETD value of 1181.3. In conducting performance evaluation, methods are needed that are appropriate to the state of the company. And employees need training to improve performance.

3. Evaluate the effectiveness of communication (PA5).

Risk mitigation action with the third rank that has a kindergarten value of 1059, a value of Dk of 4, and for an ETD value of 264.75. Evaluation of communication effectiveness needs to be done to find the root cause of communication disruption.

4. Perform performance measurements (PA4).

Risk mitigation action with the fourth rank that has a kindergarten value of 2790 , a dk value of 4 , and an ETD value of 252. The workforce must be measured to show performance so far to be adjusted to the standards in the company.

5. Conduct training periodically (PA3).

Mitigation action with the fifth rank that has a kindergarten value of 930, a Dk value of 5, and for an ETD value of 186. Companies need to conduct regular training to improve the performance of employees and maintain the potential of employees in doing the job.

\section{Conclusion}

From the results of research that has been conducted at PT XYZ related to the procurement of elementary school books, it can be concluded that the identified risks are likely to arise in the procurement activities of PT XYZ.The advantage of using the House of Risk method is that it calculates possible risk events caused by several risk agents and risk events that cause some risk events that are not considered by other risk mapping methods.

Risk event in the procurement of PT XYZ identified as much as 10 , while for risk agents identified as many as 10 and prioritized to be mitigated based on the value of ARP as much as 2 namely risk agent A1 (Volume and type of raw materials is not appropriate) and A3 (communication interruption).

Mitigation or prevention strategies prioritized to prevent the cause of risk are conducting a review of the effectiveness system for procurement activities, evaluating supplier performance, evaluating the effectiveness of communication, conducting performance measurements, and conducting training periodically.

\section{References}

Bailey, P. (2015). Procurement, Principles \& Management (11 ed.). Pearson.

Besterfield. (1999). Total Quality Management. Prentice Hall International, Inc. USA.

Muhlbauer, W. Kent. (1992). Pipeline Risk Management Manual. Houston: Gulf Publishing Company.

Magdalena, R., \& Vannie, V. (2019). Analisis Risiko Supply Chain dengan Model House of Risk (Hor) pada PT Tatalogam Lestari. J@ti Undip: Jurnal Teknik Industri, 14(2), 53-62.

Pujawan, I. N., \& Geraldin, L. H. (2009). House of Risk: A Model for Proactive Supply Chain Risk Management. Business Process Management Journal.

Sinha, P. R., Whitman, L. E., \& Malzahn, D. (2004). Methodology to Mitigate Supplier Risk in An Aerospace Supply Chain. Supply Chain Management: An International Journal.

Tang, C. S. (2006). Robust Strategies for Mitigating Supply Chain Disruptions. International Journal of Logistics: Research and Applications, 9(1), 33-45.

van Weele, A. J. (2010, October). Value Creation and Purchasing Strategy. In International Trade Forum (No. 4, p. 34). International Trade Centre.

Yuliawati, E. (2015). Pengelolaan Bahan Baku dengan Pendekatan Analisis Risiko dan Pengendalian Persediaan. 